\title{
Relationship Between Staff Development and Job Performance Among Personnel in Branch Libraries, University of Maiduguri,Nigeria
}

\author{
Katamba Abubakar Saka \\ Department of Library and Information Technology, Federal University of Technology, Minna. Nigeria \\ Ibrahim Haruna \\ Department of Library and Information Science, University of Maiduguri, Maiduguri. Nigeria
}

\section{Doi:10.5901/mjss.2013.v4n5p9}

\section{Abstract}

This study investigated Staff development as a motivating factor in job performance among personnel in branch libraries, University of Maiduguri. The study aimed at determining the relationship between staff development programmes and job performance. It was a survey research method involving 47 (professional, paraprofessional and non- professional) staff in 15 branch libraries. The entire population of 47 staff was adopted for the study and so there was no sampling. Questionnaire was the only research instrument used in data collection. Questionnaire was divided into six sections (Demographic variables of respondents, formal education, seminars/Conferences, workshop attendance, and job performance). The instrument also comprises 15 items within the six sections. The 47 copies of questionnaire were administered and retrieved by the researchers. Data were analyzed by descriptive and inferential statistics. Descriptive statistics was used to analyze demographic variables of respondents. While inferential statistic i.e Pearson Product Moment Correlation (PPMC) was used to test the four formulated hypotheses, while Multiple Regression Analysis was used to test one (1) null hypothesis on the joint relationships between staff development programme and job performance at 0.05 level of significance. Response rate showed that out of the forty seven (47) copies of questionnaire administered, 34 (72\%) copies were returned and found usable. Majority of the respondents were males while professional staff were the majority of respondents. Hypotheses tested revealed that formal education does not enhance job performance of staff. On the other hand Seminars/conferences and workshop attendance enhances job performance of staff. As the staff development programmes collectively increases, the job performance of staff tends to be higher. Conclusion was that there was indiscipline on the part of staff and that there was no enforcement of discipline by the management despite opportunities for formal education in the university. The increase in opportunities for the various staff development programmes increase higher job performance on the part of staff in branch libraries. Among the recommendations include strict enforcement of discipline on staff and creating opportunities for staff development by the University management.

Keywords: Motivation, staff development, job performance, branch libraries, relationship, University of Maiduguri.

\section{Introduction}

Productivity in any organization is largely determined by the quality of personnel and how the organization is able to develop them. This has to do with the concept of motivation. This concept is concerned with the class of drives, desires, and needs etc that influence individual behaviours (Shehu, 2001). Those things that positively influence human behaviours to perform efficient job can be referred to as motivational factors (Haruna, 2003) motivational strategies (Tella, Ayeni and Popoola, 2007). Hosoi (2005) identify some theories that bear relationship with motivational factors and they include Maslow's hierarchy of needs, Alderfer's ERG theory, Mc Clelland's theory of socially acquired needs as well as Hezberg's motivational-hygiene theory, 
among others. Management can motivate staff to perform efficiently through promotion, increase in salaries and wages, effective communication of ideas among staff, award, participatory management and staff development, among others. It is assumed that the more staff are motivated the more they perform and thus lead to higher productivity.

Staff development can be regarded as series of activities an organization put in place in order to assist its staff members acquire the skills and knowledge necessary for efficient and effective performance of jobs and responsibilities in the organization (Banta, 2008). Therefore, staff development is the provision of skills to enable staff members effectively perform their jobs. The types of staff development programme include: simple orientation programme, organized visit, seminars and conferences, participatory management, internal training programmes, formal professional library education and short courses (Ifidon, and Ifidon, 2007) and according to Mohammed (2010) posited that all these training programmes can help both professional and para-professional staff to be current with new knowledge and development in the field. It follows thus, that the more staff undergo staff development programmes, the more committed they are to job performance.

Job performance on the other hand is the ability to carry out statutory functions which are based on the field of specialization or areas of development as well as an organization's objectives. According to Villamova, Austin and Borman (2005) cited Austin et al (1991), job performance is defined "as that aspect of work behaviour domain that is of relevance to the job and organization success". Jobs performed in library include cataloguing and classification of materials, provision of reference services, charging and discharging of materials to users etc. Job performance in library situation is geared towards meeting not only the users' information needs but also it is a basis or a criteria for promoting staff.

University of Maiduguri being a second generation university was established in 1975, while the current university library assumed the present name in 1976, after late General Murtala Ramat Muhammed (Haruna, 2003). As at now, Ramat library has 15 branch libraries (under its control). The branch libraries are those libraries established in the academic departments, faculties and research institutes and are controlled by Ramat library, University of Maiduguri.

\section{Statement of the Problem}

Library Staff are expected to perform their statutory jobs in line with the set objectives of the library. This can be achieved through provision of services to users. Individual staff member has the greatest responsibility for his/her own development and as such must show willingness to improve himself/herself; the employee must take initiative by drawing the attention of the institution to training opportunities and believe that learning is a life-long process (Ifidon and Ifidon, 2007).

From the preliminary study conducted by the researchers, it was found that the staff were not performing their assigned duties such as shelving, cataloguing, filing, reference services, etc as expected. This situation might be related to the findings by Okozor (2007) who found poor implementation of in-service training programmes to affect workers' productivity in the three states public libraries in south eastern Nigeria. This behavior may be attributed to indiscipline among the staff and lack of management's enforcement or provision for staff development programmes. This necessitated the need for this study so as to investigate whether lack of staff development might be the predictable factor responsible for poor job performance or lack of commitment to job among branch library staff. This study is therefore carried out to determine the relationship between independent variables of staff development (seminars/ conferences, workshops and formal education) and dependent variable of job performance of staff in branch libraries, University of Maiduguri. 


\section{Objectives of the Study}

The objectives of the study are to determine the:

1. Relationship between formal education and job performance of staff in branch libraries;

2. Relationship between seminars/conferences and job performance of staff in branch libraries;

3. Relationship between workshop attendance and job performance of staff in branch libraries;

4. Joint relationship between independent variables of staff development and job performance.

\section{Hypotheses}

The following null hypotheses were tested (at 0.05 level of significance) for the study:

1. There is no significant relationship between formal education and job performance of staff in branch libraries.

2. There is no significant relationship between seminars/conferences and job performance of staff in branch libraries.

3. There is no significant relationship between workshop attendance and job performance of staff in branch libraries.

4. There is no high strength of relationship between independent variables of staff development and job performance of staff in branch libraries.

\section{Significance of the Study}

The study findings would be beneficial to the University librarian, library staff and University Administration. The findings would serve as a guide for librarians' decision-making in motivating the staff through staff development programmes through sourcing adequate funds. Library staff would also know the factors responsible for lack of their job performance such as lack of opportunities for staff development. While University administrators would be aware of why the library staff is not performing (well) effectively. This can be known if bad/poor performance is noticed on the part of library staff.

\section{Scope of the study}

The scope covers staff working in branch libraries, University of Maiduguri and it is to determine the relationship between independent variables of staff development motivating factors (formal education, seminar/ conferences, and workshops) with job performance. Branch libraries within the context of this study are departmental, faculty and research institute libraries which are controlled by Ramat library, University of Maiduguri.

\section{Review of Related Literature}

Okozor (2007) reported that poor implementation of the in-service training programme affected workers' productivity in Anambra, Ebonyi and Enugu states public libraries in Nigeria. Saka (2008) studied staff development in relation to job performance in selected academic libraries, University of Maiduguri, using 30 staff as sample size. The result showed significant relationship between educational qualification and job performance and high correlation between training programme and job performance. There was no significant relation between job satisfaction and job performance in selected academic libraries.

Mbagwu \& Nwachukwu (2010) examined the training and development programmes benefited and its effects on professional and para-professional staff inn FUTO library using descriptive statistics. It found that induction and orientation, on-the-job training, workshop, seminars and conferences; simulation and extension 
training are the kinds of training and development available in FUTO library. The study revealed that training and development enhance job performance as majority of the respondents affirmed that job performance is above average after undergone training.

Adomi and Famola (2012) investigated training and development of 50 cataloguers in National Library of Nigeria, Abuja. Questionnaire was used to collects data. The study found perceived staff development and training as to improve quality of library staff service delivery. It enhance job satisfaction and staff become competent

\section{Methodology}

Survey research method was used in the study. The population for the study comprises 47 staff in 15 branch libraries, University of Maiduguri. See table below:

\section{Population of staff in branch libraries, university of Maiduguri}

\begin{tabular}{|c|c|c|}
\hline & Branch libraries & Number of staff \\
\hline 1. & Agro vet library & 6 \\
\hline 2. & Aminu Kano Law library & 5 \\
\hline 3. & Faculty of Engineering & 6 \\
\hline 4. & Faculty of Pharmacy & 2 \\
\hline 5. & Faculty of Science & 2 \\
\hline 6. & Harold Scarborough Medical library & 6 \\
\hline 7. & J.D. Amin library(Faculty of Education) & 4 \\
\hline 8. & Arabic/lslamic studies library & 3 \\
\hline 9. & Radiography library & 1 \\
\hline 10. & Nursing library & 1 \\
\hline 11. & Pre-clinical library & 3 \\
\hline 12. & Arid zone library & 3 \\
\hline 13. & Trans-Sahara library & 2 \\
\hline 14. & Prof. Brann library of language in Education and society & 2 \\
\hline \multirow[t]{2}{*}{15.} & Centre for Peace, Diplomatic and Development studies & 1 \\
\hline & Total & 47 \\
\hline
\end{tabular}

Source: Field Survey, 2009.

The population of 47 staff in all the 15 branch libraries of Ramat Library was not sampled simply because it was manageable; thus it was adopted. This is in line with the assertion made by Afolabi (1999) that a researcher can adopt the entire population in a study if it is manageable and accessibility to subjects of the study will not create problem in terms of cost. Permission was sought from heads of respective branch libraries before administering copies of the questionnaire. Letter of introduction was attached to each of the 47 copies of questionnaire and were self-administered by the researchers. Out of the 47 copies of questionnaire distributed, 34 (72\%) were returned and found usable.

\section{Data Analysis and Discussion}

Data were analyzed by descriptive and inferential statistics. Descriptive statistics was used to analyze data on the response rate and demographic information of respondents. Inferential statistics was used to analyze data on the relationship between independent variables of staff development and Job performance using PPMC and multiple regression analysis to test the four null hypotheses respectively at 0.05 level of significance. 


\section{Response Rate}

Out of the 47 copies of questionnaire administered, 34 (72\%) were returned and found usable. This might be attributed to the fact that the copies of questionnaire were self-administered and collected back by the researchers.

\section{Demographic Information of Respondents}

Table 1: Respondents by Gender

$\begin{array}{lcc}\text { Gender } & \text { Frequency } & \text { Percentage (\%) } \\ \text { Male } & 21 & 62 \\ \text { Female } & 13 & 38 \\ \text { Total } & 34 & 100\end{array}$

The table above revealed gender disparity among respondents as 21 (62\%) were males, while 13 (38\%) were females working in 15 branch libraries of the University of Maiduguri.

Table 2: Respondents by Cadre

$\begin{array}{lcc}\text { Cadre } & \text { Frequency } & \text { Percentage (\%) } \\ \text { Professional } & 18 & 53 \\ \text { Para-Professional } & 11 & 32 \\ \text { Non-Professional } & 05 & 15 \\ \text { Total } & 34 & 100\end{array}$

The cadre of respondents were examined and found that $18(53 \%)$ were professional staff holding bachelor and masters degrees in librarianship. This showed that each of the 15 branch libraries was headed by a professional staff. The next cadre was the Para-professional staff with 11 (32\%) respondents holding certificate, diploma and /or higher diploma in librarianship. They assist the professional staff in the performance of jobs in branch libraries under study. The other cadre of library personnel was nonprofessional staff and was 5 (15\%). This category of staff neither has background in librarianship nor holds any qualification in librarianship.

Table 3: Working Experience of Respondents

Years of Experience
0-4 Years
5-10 Years
11-15 Years
16-20 Years
21 and above
Total

$\begin{array}{cc}\text { Frequency } & \text { Percentage (\%) } \\ 04 & 12 \\ 08 & 24 \\ 08 & 24 \\ 07 & 20 \\ 07 & 20 \\ 34 & 100\end{array}$

The table revealed that $8(24 \%)$ respondents had between 5 and 10 years as well as 11 and 15 years of working experience respectively. These further showed that the 16 staff took appointment between late 1990s and early 2000's. Data further showed that between 16 and 20 years and 21 years and above 7 (20\%) respondents respectively had worked in branch libraries which signifies that they took appointment with the university between late 1980's and early 1990's. Few staff had between zero and 4 years working experience and they are likely to be the new entrants in the profession. 


\section{Testing of Null Hypotheses}

Data were analyzed by inferential statistics using Pearson Product Moment Correlation (PPMC) coefficient to investigate the relationship between independent variables of staff development and job performance of staff. Multiple regression analysis was used to study the joint relationships between independent variables of staff development and dependent variable of job .performance. The four null hypotheses were tested at 0.05 level of significance.

The analyses were carried out using Statistical Package for Social Science (SPSS) version 16. Pearson Product Moment Correlation method (PPMC) was employed to analyze the relationship between the attributes, while Multiple Regression was used to determine the joint effect of other variables (independent) on job performance. All the results were based on 0.05 level of significance. The results are presented below with the hypotheses.

Hypothesis 1: There is no significant relationship between formal education and job performance of staff in branch libraries.

Table 4: Relationship between formal education and job performance in branch libraries

\begin{tabular}{|l|c|c|c|c|c|c|c|}
\hline Variables & $\mathrm{N}$ & $\overline{\mathrm{X}}$ & $\mathrm{S} . \mathrm{D}$ & $\mathrm{df}$ & r-value & $\mathrm{p}$-value & Decision \\
\cline { 1 - 7 } Formal education & & 2.76 & 0.496 & & & & \\
\cline { 1 - 6 } Job performance & \multirow{2}{*}{34} & 2.15 & 1.105 & 33 & -0.0101 & 0.570 & Accepted \\
\hline
\end{tabular}

Table 4 shows that the calculated r-value was - .0101 with mean of 2.76 and standard deviation of 0.496 with $\mathrm{df}$ of 33 , while job performance of library staff has a mean of 2.15 and standard deviation (SD) of 1.105. Since the $r$ - value of -.0101 is lower than the P-value of .570 , therefore the null hypothesis is accepted. Therefore, there is no significant relationship between formal education and job performance. This showed that even with the possession of requisite qualifications not all library staff are dedicated and committed to duty. It can also be inferred that not all branch library staff are ready to pursue formal education in librarianship despite opportunities available in the university

Hypothesis 2: There is no significant relationship between seminars and job performance of staff in branch libraries.

Table 5: Relationship between seminars/conferences and job performance of staff in branch libraries

\begin{tabular}{|l|c|c|c|c|c|c|c|}
\hline Variables & $\mathrm{N}$ & $\overline{\mathrm{X}}$ & $\mathrm{S} . \mathrm{D}$ & $\mathrm{df}$ & $\mathrm{r}$-value & $\mathrm{p}$-value & Decision \\
\hline Seminars/Conferences & \multirow{3}{*}{34} & 1.97 & 0.627 & & & & \\
\cline { 1 - 3 } Job performance & 2.15 & 1.105 & 33 & 0.444 & 0.009 & Rejected \\
\hline
\end{tabular}

Table 5 shows the calculated r-value of 0.444 with mean of 1.97 and standard deviation of 0.627 with df 33 , while the job performance of staff had a mean of 2.15 and standard deviation of 1.105. Since r-value of 0.444 is greater than the P-value of .009 , it implies that there exists relationship between seminars/conferences and job performance. This shows that seminars/conferences enhance job performance. Therefore, the null hypothesis is rejected.

Hypothesis 3: There is no significant relationship between workshop attendance and job performance of staff in branch libraries. 
Table 6: Relationship between workshop attendance and job performance of staff in branch libraries

\begin{tabular}{|c|c|c|c|c|c|c|c|}
\hline Variables & $\mathrm{N}$ & $\bar{x}$ & S.D & df & r-value & $p$-value & Decision \\
\hline Workshop attendance & & 2.0 & 0.779 & & & & \\
\hline Job performance & 34 & 2.15 & 1.105 & 33 & 0.352 & 0.041 & Rejected \\
\hline
\end{tabular}

Table 6 shows the calculated value. 0.352 with mean of 2.0, with df 33 , while the job performance of staff has a mean of 2.15 and SD of 1.105. Since the calculated r-value of .0 .352 is greater than the P-value of 0.041 , thus there is low strength of relationship between workshop and job performance. The null hypothesis is rejected. There is significant relationship between workshop attendance and job performance of staff in branch libraries.

Hypothesis 4: There is no joint relationship: between job performance and formal education, seminar/conference and workshop attendance.

Table 7A Joint relationship between staff development and job performance of staff in branch libraries

\begin{tabular}{|l|c|c|c|c|}
\hline & ANOVA & MS & F & Sig. Value \\
\hline Regression & 14.563 & 3.641 & 4.108 & 0.009 \\
\hline Residual & 25.701 & 0.886 & & \\
\hline Total & 40.265 & & & \\
\hline
\end{tabular}

Table 7B Joint relationship between staff development and job performance of staff in branch libraries

\begin{tabular}{|l|c|c|c|c|}
\hline & B & Std. error & T & Sig. value \\
\hline Constant & -1.302 & 1.393 & -0935 & 0.358 \\
\hline Formal education & 0.224 & 0.355 & 0.632 & 0.532 \\
\hline Seminars/Conferences & 0.789 & 0.275 & 2.874 & 0.008 \\
\hline Workshops & 0.519 & 0.236 & 2.196 & 0.036 \\
\hline
\end{tabular}

From the tables, the model for the joint relationship is significant $(P<0.05)$ as shown by the ANOV A table. The joint correlation coefficient $\mathrm{R}=0.601$ coefficient of determination $\mathrm{R} 2=36.2 \%$ showing that $36.2 \%$ of the variation in job performance was accounted for by the joint effect of formal education, seminars/conferences, workshops. The model is thus:

Job performance $=1.302+0.224$ formal education +0.789 seminars +0.519 workshops. But only seminars/conferences and workshops are significant thus the correct model for predicting job performance is:

Job performance $=0.789$ seminars +0.519 workshops. The implication here is that as opportunity for individual staff development programme increase the job performance tends to increase higher.

\section{Discussion}

The study examined the relationship between independent variables of staff development and job performance by staff in branch libraries, University of Maiduguri. Out of four null hypotheses of no significant relationship between formal education; Seminars/Conferences, workshop and job performance of library staff; only formal education tends not to have significant relationship with job performance of staff in branch 
libraries. The fourth hypothesis shows that the four variables of staff development were highly correlated with job performance.

There was no relationship between formal education and staff job performance. This finding corroborated with the finding of Okozor (2007) who discovered poor implementation of in-service training programmes to affect workers' productivity in three states public libraries. On contrary, Saka (2008) discovered significant relationship between education qualification and job performance of library staff.

Hypotheses 2 and 3 revealed significant relationship between seminars/conferences; workshop attendance and job performance. These finding corroborate that of Mbagwu \& Nwachukwu (2010) who found seminars/conferences; workshop attendance, on-the-job training, stimulation and extension training were not only available but also enhance job performance of library personnel.

The result showed that the strength of relationship between staff development programmes and job performance was highly significant with R-value of $60 \%$. This finding corroborate that of Saka (2008), Mbagwu and Nwachukwu (2010) and Adomi \&, Famola (2012) who discovered that staff development programmes to only enhance job performance but also there is high significant relationship between staff development and job performance among library personnel

\section{Summary of Findings}

Based on the analysis and discussion, the following are the major findings of the study:

1. there was no significant relationship between formal education and job performance of staff in branch libraries;

2. There was significant relationship between Seminars/Conferences and Job performance of staff in branch libraries;

3. There was significant relationship between Workshop attendance and job performance of staff branch libraries;

4. There was high correlation among formal education, seminars/conferences, and workshop attendance and job performance of staff in branch libraries.

\section{Conclusion}

From the findings, it can be concluded that in spite of various forms of formal education available in the university, there was indiscipline on the part of library staff due to lack of dedication and commitment to duties even with the possession of requisite qualifications. It can therefore be deduced that University management was unable to enforce discipline on staff to check this negative attitude. The increase in the opportunities of various staff development programmes in the University enhances higher job performance of staff in branch libraries.

\section{Recommendations}

Based on the findings of this study the following recommendations are made:

1. Indiscipline on the part of staff be checked and management should enforce discipline on staff for them to justify the skills acquired during the formal education programme;

2. Management of University Library should sponsor library staff to attend seminars/conferences and workshops, while in-house training be organized for staff in branch libraries on regular basis;

3. The management of Ramat library should include practical aspect of librarianship in planning for workshop for its staff.

4. The management of Ramat library should endeavour to see that each of the independent variables of staff development contributes towards effective job performance of staff in branch libraries, 
University of Maiduguri. This can be achieved through regular and adequate funding of various staff development programmes.

\section{References}

Adomi, E.E \& Famola, M.O (2012) Training and development of catalogues in National Library of Nigeria. Nigerian Libraries 45(1) 68-77

Afolabi, M. (1999). Research Methodology. In Alkaleri, A.U (ed). Fundamentals of Librarianship. Kaduna: Academic Press, 29-40.

Banta, R.C. (2008). Staff Development and Continuing Education in a Technological University Library in Nigeria: The ATBU Example. Gateway Library Journal, 11 (1), 25-32.

Eke, H. N. (2011). An empirical study of the impact of the NLA conference attendance on Librarians professional development. Proceedings of 49th National Conference and AGM of the NLA held at Emmaus House Complex, Awka, 10-15 July, 2011, 118-139.

Etubi, M and Ikekhai, M.O (2007). Retrospective Conversion: Our experience in University of Jos Library. Information Technologist, 4 (1), 92-94

Haruna, I. (2003). Motivational Factors as Correlates of Employees' performance in Ramat Library, University of Maiduguri. Annals of Borno, 19/20,89-95.

Hosoi, I. (2005). Motivating Employees in Academic Libraries in Tough Time. Association of College and Research Libraries, ACRL, 43-49.

Ifidon S.E. and Ifidon E.I (2007). New Directions in African University Library Management. Ibadan: Spectrum Book Limited, 134-140.

Mohammed, A. (2010), Manpower Development in Libraries: A challenge Facing Law Librarians in Nigeria. Borno Library, Archival and Information Science Journal A publication of the Nigerian Library Association, Borno State chapter 9(1), 105, $110-111$.

Okozor, E.U. (2007). Factors affecting workers' productivity in public libraries: A case study of Anambra, Ebonyi and Enugu states public libraries. Unpublished MLS, University of Nigeria, Nsukka, 102p.

Saka, K.A. (2008). Staff development as a Motivating factor in job performance of staff in selected branch Libraries of Ramat Library, University of Maiduguri. Journal of Information Resource management: journal of Niger State chapter of Nigerian Library Association, 1(1), 34-42

Shehu, A. (2001). Administrative and Management Theories. Minna: Global and Associate, 119-120.

Tella, A., Ayeni, C.O \& Popoola, S.O. (2007). Work Motivation, Job Satisfaction and Organizational Commitment of Library Personnel in Academic and Research Libraries in Oyo State, Nigeria. Library Philosophy and Practice eJournal 1-12, http://digital common.edu/libphilopra/118. Accessed on May 5, 2011.

Villamova, P, Austin, J.T. and Borman, W. (2005) Job performance. Blackwell Encyclopedia of management. 2nd edition, vol. 5, Cartwright, C. (eds), United Kingdom: Blackwell publishing, 208-209. In Austin, J.T. et al (1991) 
